\section{Kastamonu Eğitim Dergisi Kastamonu Education Journal}

Kasım 2019 Cilt:27 Sayı:6

kefdergi.kastamonu.edu.tr
Başvuru Tarihi/Received: 9.04.2019

Kabul Tarihi/Accepted: 14.06.2019 DOI: $10.24106 /$ kefdergi.3707

\title{
Bilimsel Araştırmalara Yönelik Öğretmen Öz Yeterlilik Ölçeğinin Geliştirilmesi
}

\section{The Development of the Teachers' Self-Efficacy Scale Regarding Scientific Researches}

\section{Öz}

\author{
Alptürk AKÇöLTEKIN ${ }^{1}$
}

Bu araştırmanın amacı, öğretmenlerin bilimsel araştırmaya yönelik öz-yeterlilik düzeylerini belirlemek için bir ölçme aracı geliştirmektir. Çalışmaya farklı branşlarda görev yapan 556 öğretmen katımıştır. Açımlayıcı faktör analizi, birinci ve ikinci düzey doğrulayıcı faktör analizi ve güvenilirlik analizi sonucunda elde edilen öz-yeterlilik ölçeğinin yüksek geçerlilik ve güvenilirliğe sahip olduğunu göstermiştir. Yapılan açımlayıcı ve doğrulayııı faktör analizi sonucu 6 faktörden ve 37 maddeden oluşan ölçek elde edilmiştir. Ölçeğin iç geçerliği, \%27'lik üst ve alt gruplar 'bağımsız gruplar $\mathrm{t}$ testi' ile değerlendirilmiş ve farkın istatistiksel olarak anlamlı olduğu sonucuna ulaşılmıştır. Elde edilen sonuçlara göre ölçek 6 faktörlü bir yapı göstermekle birlikte ölçeğin geneli için güvenirlik katsayısı 0,92, faktörler için ise sırasıyla raporlaştırma 0,92; veri analizi 0,81; literatür tarama 0,89; yöntem 0,89; hipotez(ler)i belirleme 0,88 ve problemi tanımlama 0,86 olarak hesaplanmıştır. Doğrulayıcı faktör analizi çalışmaları sonucuna göre, önerilen modele ilişkin uyum indekslerinden GFI (0.77), CFI (0.97), NFI (0.95), RMSEA (0.073), CFI (0.97), AGFI (0.73), SRMR (0.062) olarak hesaplanmıştır. Sonuçlar ölçeğin öğretmenlerin bilimsel araştrrmaya yönelik öz-yeterlilik algılarını ölçmek için uygun olduğunu göstermektedir.

Anahtar Kelimeler: bilimsel araştırma yöntemleri, öz yeterlilik, öğretmenler

\section{Abstract}

The aim of this study is to develop an assessment tool in order to identify the self-efficacy levels of teachers regarding the scientific research. 556 teachers, teaching on various fields of education, have participated in the study. The data acquired from the exploratory factor analysis, primary and secondary level confirmatory factor analysis and reliability analysis show that self-efficacy scale has high validity and reliability. As a result of the exploratory and confirmatory factor analysis, a scale, composed of 6 factors and 37 articles was attained. The internal validity of the scale is assessed through the super- and sub-groups of $27 \%$ 'independent samples t-test' and it was concluded that the variation is statistically meaningful. According to the results, along with the 6-factors structure of the scale, it was calculated that the reliability co-efficient of the overall scale is 0,92 , and for the factors, respectively, reporting is 0,92 ; data analysis is 0.81 ; literature review is 0,89 ; method is 0,89 ; identifying hypothesi(e)s is 0,88 and defining the problem is 0,86 . As to the result of the studies of confirmatory factor analysis, the compatibility indexes regarding the recommended model are calculated as GFI (0.77), CFI (0.97), NFI (0.95), RMSEA (0.073), CFI (0.97), AGFI (0.73), SRMR (0.062). The results indicate that the scale is suitable for assessing the self-efficacy perceptions of the teachers regarding the scientific research.

Keywords: scientific research methods, self-efficacy, teachers

1. Ardahan Üniversitesi, Beden Eğitimi ve Spor Yüksekokulu, Beden Eğitimi ve Spor Öğretmenliği Bölümü,Ardahan,Türkiye; https://orcid.org/0000-0001-6694-1346 Atff / Citation: Akçöltekin, A. (2019). Bilimsel araştırmalara yönelik öğretmen öz yeterlilik ölçeğinin geliştirilmesi. Kastamonu Education Journal, $27(6), 2713-2727$. doi:10.24106/kefdergi.3707 


\section{Extended Abstract}

Introduction: In the changing world, the needs of the society have also been rapidly changing, and the scientific research as well as the sufficiency of the researchers are of great importance for educating the human power that can respond to these needs. It is of great importance that teachers who are obliged to teach the skills of researching-investigating, problem-solving and critical thinking to the young people should, first of all, possess these skills and competencies. Raising teachers with research skills, using research techniques, studying scientific research and having positive attitude and self-efficacy in scientific research can be possible through the training regarding scientific research, which will be given by educational institutions. In this context, the teachers should be educated in scientific research, in the first place.

Method: This study, conducted in screening model, was carried on participants using the random sampling method from Ardahan province in 2018. This study aims to develop an assessment tool in order to identify the self-efficacy of the teachers regarding the scientific researches. In accordance with this aim, after constituting an item tool of 48 articles, exploratory factor analysis is conducted by applying the attained data to 318 teachers and and 218 teachers for confirmatory factor analysis teaching at various fields of education. In order to determine the distinctiveness of the scale, the relation between the sub-groups with the $27 \%$ and super-groups with the $27 \%$ is analyzed through the t testing and it is concluded that there is a statistically meaningful difference between the groups and the distinctiveness within the articles is high and that it has the internal validity. In the study, Kaiser-Meyer-Olkin (KMO) and Bartlett tests were used to examine whether data was suitable for factor analysis. Exploratory factor analysis (EFA) was used in structure validity of the scale, and confirmatory factor analysis (CFA) was applied to test accuracy of factor structure obtained as a result of previous analysis. In reliability study, internal consistency (Cronbach's Alpha) values were calculated. In addition to CFA was used to analyse model fit of the scale obtained with EFA. Multiple fit indices (X2, sd, X2/sd, RMSEA, CFI, GFI, AGFI, SRMR, NFI) were used in CFA.

Findings: As the result of the analysis, firstly the articles with a total item correlation value 0,40 and over are left within the scale. According to the analysis, it was detected that the factor load value of 37 articles of the scale is 0,40 and over. For all of the articles of the scale with the value of 0,40 and above, a second factor analysis is applied and this time it is identified that the KMO value of the scale is 0,96 . According to the result of Bartlett's test for sphericity, this value of the scale is identified as $[\chi 2=7838,972 / s d=666 ; p<0,000]$. For this study also the eigenvalue is addressed as 1,00 and six factors are detected to be over the eigenvalue of 1,00 . As the load values of these six values are assessed, it is identified that the articles within the dimension of "Reporting" vary from 0,708 to 0,675 and explain the $19,19 \%$ of the total variance; the articles within the dimension of "Data Analysis" vary from 0,632 to 0,467 and explain the $12,39 \%$ of the total variance; the articles within the dimension of "Literature Review" vary from 0,754 to 0,604 and explain the $11,32 \%$ of the total variance; the articles within the dimension of "Method" vary from 0,717 to 0,621 and explain the $9,74 \%$ of the total variance; the articles within the dimension of "Identifying Hypotheses(e)s" vary from 0,701 to 0,560 and explain the 9,30\% of the total variance; and finally the articles within the dimension of "Problem Defining" vary from 0,848 to 0,478 and explain the 2,99\% of the total variance; and that the factors explain the $64,95 \%$ of the total variance.

When the values of the goodness of fit gathered as the result of the primary-level confirmatory factor analysis are analyzed, the outcome is identified as $\chi 2(s d, N)=(1327,63 ; 610 ; 238), \chi 2 / s d=2,176$; RMSEA $=0,070 ; \mathrm{S}-\mathrm{R}$ $\mathrm{MR}=0,065 ; \mathrm{AGFI}=0,71 ; \mathrm{NFI}=0,94 ; \mathrm{NNFI}=0,96 ; \mathrm{CFI}=0,97$ and IFI=0,97. According to the data, the scale-detected values of the model indicate that the data exhibits acceptable concordance. In other words, this model, which is acquired, reveals that the factors are confirmed by the data. When the values of the goodness of fit gathered as the result of the secondary-level confirmatory factor analysis are analyzed, the outcome is identified as $\chi 2 / \mathrm{sd}, \mathrm{N}$ $(1405,21 ; \mathrm{sd}=619, \mathrm{~N}=238), \mathrm{RMSEA}=0,073 ; \mathrm{S}-\mathrm{RMR}=0,062 ; \mathrm{GFI}=0,077 ; \mathrm{AGFI}=0,73 ; \mathrm{CFI}=0,97 ; \mathrm{NNFI}=0,97 ; \mathrm{IFI}=0,97$; $\mathrm{NFI}=0,95$. These acquired-data shows that the data compatibility of the model is sufficient. When the factor loads $(\lambda x), t$ values, measurement errors (delta, $\delta$ ) between the primary level latent variables and "self-efficacy", which is the upper level (secondary level) variable, along with the explanation rates (R2) of the secondary-level variable within the primary-level variables, are all analyzed within the scale, it is detected that the relation between the self-efficacy and all other factors is positively and meaningful looking at the path coefficients and $t$ values between secondary level self-efficacy latent variable and the first latent variable $(\lambda x=2,13 ; p<0,05 ; t=7,72)$, the second latent variable $(\lambda x=2,12 ; p<0,05 ; t=7,15)$, the third latent variable $(\lambda x=1,40 ; p<0,05 ; t=8,90)$, the fourth latent variable $(\lambda x=1,64 ; p<0,05 ; t=6,63)$, the fifth latent variable $(\lambda x=1,00 ; p<0,05 ; t=8,71)$ and the sixth latent variable $(\lambda x=1,08$; $p<0,05 ; t=8,26)$.

The meaningfulness of the $t$ values of all the factors of the model and the $t$ values of the factors located within the model is a requirement for the acceptability of the model. Looking at the variants explained by secondary level self-efficacy latent variable within primary level variables, among the primary level variables, the variability is

| Kastamonu Eğitim Dergisi, 27(6), 2019| 
explained at the very most within the variable of reporting $(R 2=0,82)$ and at the very least within the variable of literature review $(R 2=0,15)$. As a conclusion, the developed scale is detected to have structure of a 5 point Likert type, with 37 articles and 6 factors. The structure of scale is consisted of the first factor "Reporting" with 7 articles $(1,2,3,4,5,6,7)$; the second factor "Data Analysis" with 6 articles $(8,9,10,11,12,13)$; the third factor "Literature Review" with 7 articles $(14,15,16,17,18,19,20)$; the fourth factor "Method" with 6 articles $(21,22,23,24,25,26)$; the fifth factor "Identifying Hypotheses(e)s" with 5 articles (27, 28, 29, 30, 31); and finally "Problem Defining" with 6 articles $(32,33,34,35,36,37)$. While the Cronbach's alpha reliability co-efficient of the overall scale is discovered as 0,95 , the reliability co-efficient of the factors are calculated respectively as 0,$92 ; 0,81 ; 0,89 ; 0.89 ; 0,88$ and 0,86 .

During the scoring of the scale, in order for each range of the levels to be equally ranged, the formula of $(n-1) / n$ is applied and the score of each level is calculated as 0,80. Accordingly, the scale and the corresponding values are identified as "Never Agree" with 1,00-1,80, "Don't Agree" with 1,81-2,60, "Hesitant" with 2,61-3,40, "Agree" with $3,41-4,20$ and "Totally Agree" with 4,21-5,00. While the minimum score to be gathered from the scale is 37 , the maximum is 185 . As the score of the scale factors increase, the self-efficacy perceptions of the teachers regarding the related dimension/s also increase. The self-efficacy perceptions of the teachers regarding the scientific research can be surmised by dividing the total scores attained from the scale into the number of articles according to the average score of the teachers. Also, the self-efficacy perceptions of the teachers related to a specific factor can be surmised by adding up scores attained from the articles of the factor and dividing score into the number of articles within the factor in-question. Additionally, if the average score attained from the articles of "The Self-Efficacy Scale of the Teachers Regarding the Scientific Research" is between the score range of 1-2,59, then it indicates negative self-efficacy perception, if it is between the score range of 2,60-3,40, then it indicates moderate self-efficacy perception, and if it is between the score range of $3,40-5$, then it indicates positive self-efficacy perception. 


\section{Giriş}

Değişen dünya ile birlikte toplumun ihtiyaç ve talepleride değişmekte ve bu ihtiyaçları karşılayabilecek donanımlı insan gücünün eğitilmesi için de öncelikli olarak eğitim konusunda yapılan bilimsel araştrrmalara büyük önem düşmektedir (Çiltaş, Güler ve Sözbilir, 2012). Bu ihtiyaçların karşılanabilmesi amacıyla yeni nesillere araştırma-inceleme, problem çözme ve eleştirel düşünme becerilerini kazandırmakta öncelikli sorumluluğu üstlenen öğretmenlerin kendilerinin bu yeterliklere sahip olmaları büyük bir önem taşımaktadır (Saracaloğlu, 2008). Araştırmacı bir yapıya sahip öğretmenler, kendilerinin gelişimi ile birlikte öğrencilerinin bireysel gelişimine ve araştırma becerilerine sahip olmalarında öncelikli bir role sahiptir (Godson, 1994). Öğretmenlerin öğrencilerini bilimsel düşünmeye, projeler üretmeye ve bilimsel araştrma yöntemlerini kullanmaya yönlendirebilmeleri için öncelikle kendilerinin bilimsel araştırma yöntem ve süreçlerine tam olarak hakim olmaları ve bu süreçleri sağlıklı bir şekilde yürütebilmeleri gerekmektedir (Akçöltekin, 2016). Bu nedenlerden dolayı öncelikle öğretmenlerin bilimsel araştırma yetisine sahip olarak yetiştirilmeleri gerekmektedir (Taşdemir ve Taşdemir, 2011). McMillan ve Schumacher (2010) bilimsel araştırmayı belli bir amaç için sistemli bir şekilde veri toplama ve verilerin analiz edilmesi; Ekiz (2009) olayları inceleme, analiz, değerlendirilme, yorumlama ve rapor süreci olarak; Karasar (2013) bir problemi çözmek için bilim üretmek veya kanıtlanmış bir bilgi elde etmek için izlenen düzenli bir yol; Creswell (2008) problemi belirleme, problemin çözümü için test edilebilir bir öneride bulunma bu tahmine ilişkin veriler toplama ve hipotez belirleme, soru veya çözümleri destekleyip desteklemediğini görmek için verileri çözümleme ve yorumlama; Punch (2005) Yıldırım ve Şimşek (2008), Balcı (2009) problemin saptanması, önermelerin hazırlanması, planlama, araştırmanın yürütülmesi ve rapor hazırlanması; Toy ve Tosunoğlu (2007) sürecin planlanması, sorusunun tespiti ve hipotezlerin kurulması, evren ve örneklemin belirlenmesi, veri toplama araçlarının geliştirilmesi ve verileri analizinin yapılması olarak ifade etmektedirler.

İlgili literatürde öz yeterlilik kavramına ilişkin tanımlar incelendiğinde, Çoban ve Sanalan (2002) öz yeterlik teorisinin Bandura'nın sosyal bilişsel teorisine dayalı olarak oluştuğunu ve bu teoriye göre bireyin davranış değişikliklerinin belli başlı görev ya da sorumlulukları yerine getirebileceği konusundaki inancı tarafindan belirleneceğini; Golightly (2007) bireyin belli bir alandaki sorumluluğu yerine getirip getiremeyeceğine yönelik hissetiği güveni; Schunk ve Pajares (2002) bireyin geçmişteki mevcut başarısıyle ilişkili olarak üçüncü şahıslar tarafindan kendisine yöneltilen olumlu veya olumsuz dönütlerle birlikte içinde bulunduğu psikolojik durumla ilişkili olarak ortaya çıktığını; Bandura (1995)'e göre öz yeterlilik bireyin maruz kaldığı bir olay karşısında nasıl düşündüğünü, neler hissettiğini, nasıl davrandığını ve kendini bu olaya karşı nasıl motive ettiği şeklinde; Zimmerman (1995) bir konu hakkında başarılı olma ve yeterliliğe sahip olma; Senemoğlu (2007) kişinin yapmayı arzuladığı şeylerden ziyade yapabilme konusundaki yetkinliğine olan inancı olarak; Guskey ve Passaro (1994) bireyin kendi yeteneklerine olan inancı ve güveni olarak; Woolfolk-Hoy ve Burke-Spero (2005) bireyin bir işi yapabilmedeki gerçek yeterlik kapasitesinden ziyade, kendi yetkinliğine ilişkin yargıları olarak; Schunk (2011) ve House (2004) akademik yaşant ve akademik başarı ile ilişkili olduğunu ve özyeterlik inancının her başarılı davranışın önemli bir öğesi olduğunu; Kurbanoğlu (2004) olumlu deneyimlerin özyeterlik inançlarının güçlenmesini sağladığını; Aşkar ve Umay (2001) kişilerin duygularında, düşüncelerinde, güdülerinde ve davranışlarında belirleyici bir etkiye sahip olduğunu ve eğitimde üzerinde durulması gereken önemli bir özellik olduğunu ve son olarak Lane, Hall ve Lane (2004) düşük özyeterlik inancı olan bireylerin zorunlu gerekçeler olmadıkça icraata bulunmalarının zor olduğunu ve bu bireylerin sorumlulukları ertelemeye yatkın olduklarını ifade etmektedir. Öz yeterlilik kavramı ile ilgili literatür incelendiğinde, öz yeterliliğin inanç, güven, telkin, motivasyon, psikolojik hazır bulunuşluk, yeterlilik, yeteneklere olan inanç ve olumlu deneyimler gibi faktörlerden hem etkilendiği hem de bu faktörleri etkileyici bir özelliğe sahip olduğu belirlenmiştir. Öz yeterliliğin eğitim öğretim faaliyetleri ile olan ilişkisi incelendiğinde, Chan (2008) eğitim kalitesini doğrudan etkileyen faktörlerden birisinin öğretmen öz yeterliliği olduğunu; Henson (2001), Küçükyılmaz ve Duban (2006) öğretmenlerin öz yeterlik inançlarının yüksek olmasının öğrenci merkezli dersler işlemekle birlikte, derslerde seçilen yöntem ve tekniklerin daha fazla öğrenci merkezli olduğunu; Atıc (2000) öğretmenlerin eğitim öğretim faaliyetlerinde gerekli olan davranışları sergileme konusundaki inançlarında öğretmen özyeterliliğinin önemli olduğunu, Betoret (2009), Skaalvik ve Skaalvik (2010), Khan, Fleva ve Qazi (2015) öz yeterlik duygusu yüksek olan öğretmenlerin yüksek bir mesleki doyum yaşadıklarını ifade etmektedir. Literatürde bilimsel araştırma yöntemlerine ilişkin tutum ve özyeterliliği ölçen ölçme araçları incelendiğinde; Akçöltekin (2016) öğretmen adaylarının bilimsel araştırmaya yönelik tutumlarını incelendiği çalışmasında, bilimsel araştırma tutum ölçeğinin lise öğretmenleri ile uyarlama çalışmasını yaptığı ve ölçeğin 4 faktörlü bir yapıda olduğu, Gök, Kabasakal ve Çetin (2015) çalışmasında lisansüstü öğrencilerin bilimsel araştırmaların yöntem boyutuna yönelik öz yeterliliklerini incelemek amacıyla 2 faktörlü bir ölçme aracı geliştirdiğini, Yaşar (2014) öğretmen adaylarının bilimsel araştırma yöntemlerine yönelik tutumlarını belirlemeye yönelik 4 faktörlü bir ölçme aracı geliştirdiği, Korkmaz, Şahin ve Yeşil (2011) öğretmen adaylarının bilimsel araştırmaya yönelik tutumlarını belirlemeye yönelik 4 faktörlü bir ölçek geliştirdiği, Tuncer ve Özeren (2012) öğretmen adaylarının bilimsel araştırmaya yönelik öz yeterliliklerinin belirlenmesi amacı ile 4 faktörlü bir ölçek geliştirdikleri, Bieschke, Bishop

| Kastamonu Eğitim Dergisi, 27(6), 2019| 
ve Garcia (1993) öğretmen adaylarının bilimsel araştırmalarına yönelik öz yeterliliklerini incelemek amacıyla 4 faktörlü bir ölçme aracı geliştirdiği ve son olarak Tuncer ve Özeren (2012) tarafindan öğretmen adaylarının bilimsel araştırma özyeterliklerini belirlemek amacıyla 4 faktörlü bir ölçme aracı geliştirdikleri belirlenmiştir.

Illgili literatür incelendiğinde, bilimsel araştırma temalı geliştirilen ölçeklerin çoğunluğunun tutumu ölçtüğü veya bilimsel araştırma özyeterliliğini ölçen ölçme araçlarının büyük çoğunluğunun ise öğretmen adayları ile geliştirildiği belirlenmiştir. Öğretmenlerin bilimsel araştırmanın geneline ve basamaklarına yönelik özyeterliliklerini belirlemek amacıyla kullanılacak bir ölçme aracı bulunmadığından dolayı geçerliği ve güvenirliği yüksek bir ölçme aracı geliştirilmesi amaçlanmıştır.

\section{Yöntem}

\section{Araştırma Modeli}

Çalışma yöntemi olarak genel tarama modeli kullanılmıştı. Tarama modeli evrende, evren hakkında genel bir yargıya varmak amacı ile evrenin tümü ya da alınacak bir grup, örnek veya örneklem üzerinde yapılan tarama düzenlemelerini kapsamaktadır (Karasar, 2000).

\section{Çalışma Grubu}

Araştırmada öncelikle "Bilimsel Araştırma Öz Yeterlilik Ölçeği" nin geliştirilmesi aşamasında araştırmaya dahil edilmeyen ve aynı coğrafi bölgede yer alan gerek şehir olanakları gerekse okul olanakları araştırmanın yapılacağı il ile denk olan farklı bir şehirde ilkokul, ortaokul ve liselerde görev yapan 318 öğretmenden açımlayıcı faktör analizi için veri toplanmıştı. Açımlayıcı faktör analizi sonucu elde edilen ölçek formunun birinci ve ikinci düzey doğrulayıcı faktör analizini yapmak için yine aynı ilde görev yapan ve araştırmaya dahil edilmeyen 238 öğretmene faktör analizi sonucu elde edilen ölçek yapısı uygulanarak elde edilen verilerle ölçeğin doğrulayıcı faktör analizi yapılarak ölçeğin nihai yapısı oluşturulmuştur. Araştırmada farklı eğitim-öğretim kademelerinde ve farklı branşlarda görev yapmakta olan toplam 556 öğretmene ulaşılmıştr. Araştırmaya katılan öğretmenlere ait demografik bilgiler Tablo 1'de sunulmuştur.

Tablo 1. Ölçek Geliştirme Çalışmasına Katılan Öğretmenlere Ait Demografik Bilgiler

\begin{tabular}{lcccc}
\hline Değişken & Açımlayıcı Faktör Analizi & $\begin{array}{c}\text { Birinci ve İkinci Düzey Doğrulayıcı } \\
\text { Faktör Analizi }\end{array}$ \\
\hline Cinsiyet & (f) & $(\%)$ & (f) & (\%) \\
\hline Erkek & 172 & 54.1 & 120 & 50.4 \\
Kadın & 146 & 45.9 & 118 & 49.6 \\
\hline Eğitim & & & & 75.6 \\
\hline Lisans & 250 & 78.6 & 180 & 20.2 \\
Yüksek Lisans & 53 & 16.7 & 48 & 4.2 \\
Doktora & 15 & 4.7 & 10 & \\
\hline Bilimsel Araştırmaya Katılıp/Kattmama & & & & 39.9 \\
\hline Evet & 91 & 28.6 & 95 & 60.1 \\
Hayır & 227 & 71.4 & 143 & 100 \\
\hline Toplam & 318 & 100 & 238 & \\
\hline
\end{tabular}

Tablo 1'de Ölçek geliştirme aşamasında örneklem grubunu oluşturan öğretmenlere ait demografik bilgiler bulunmaktadır.

\section{Ölçeğin Geliştirilmesi}

Bilimsel Araştırma Öz Yeterlilik Ölçeği'nin geliştirme sürecinde şu işlemler sırası ile gerçekleştirilmiştir: (1) Literatür taraması ve madde havuzu oluşturma, (2) Uzman görüşü alma, (3) Madde-toplam korelasyonları, (4) Madde ayırt edicilik özelliği, (5) Açımlayıcı faktör analizi, (6) Cronbach Alpha iç tutarlılık güvenirliği, (7) Alt boyutlar arasındaki korelasyonların incelenmesi, (8) Birinci Düzey Doğrulayıcı Faktör Analizi (9) İkinci Düzey Doğrulayıcı faktör analizi. Yürütülen ölçek geliştirme çalışması bu plan dahilinde tasarlanarak yürütülmüştür.

\section{Literatür Taraması ve Madde Havuzu Oluşturma}

Ölçek geliştirilmeye karar verildikten sonra ölçülmek istenen yapının belirlenmesi, literatür taraması, uzmanlarla yapılan görüşmeler gibi adımlardan sonra ölçek geliştirme süreci madde havuzu oluşturma adımıyla başlamaktadır (Erkuş, 2014). Madde havuzu oluşturulması aşamasında öncelikle; öncelikle farklı eğitim-öğretim kademesinde görev 
yapan öğretmenlerle $(n=6)$ görüşmeler yapılmıştr. Bu görüşmelerde öğretmenlerin bilimsel araştırmaya yönelik verdikleri cevapları incelenerek analiz edildikten ve ikinci aşama olarak ise, alan yazın incelenerek öğretmenlerin ve öğretmen adaylarının bilimsel araştırma tutum ve öz yeterliklerini ölçmek amacıyla geliştirilen ölçme araçları ayrıntılı olarak incelenmiştir. Ölçülmek istenilen niteliklerin iyi örnekleyebildiği ve kapsadığı düşünülen 48 ifadeden oluşan bir madde havuzu hazırlanmıştır. Bir sonraki aşamada ise maddelerin değerlendirilmesinde yeterli uzunlukta olmaları, anlaşılır olmaları, olgusal ifadeler içermemesi, yönlendirici ve taraflı ifadeler bulundurmaması ve dilbilgisi bakımından doğru olmaları konusunda gerekli düzeltmeler yapılmıştır.

\section{Uzman Görüşü Alma}

Oluşturulan 48 maddelik ölçek formu uzman görüşleri alınmak üzere konu alanında bilgi sahibi olan ve çalışma konusu hakkında bilgilendirilen Eğitim Bilimleri alanında uzman 6 ve ölçek geliştirme konusunda 4 uzmanın görüşüne sunulmuş ve uzmanlardan elde edilen dönütlerin değerlendirilebilmesi için her bir madde için "uygun", "kısmen uygun" ve "uygun değil" şeklinde 3'lü derecelendirme kullanılmıştr. Uzmanların görüşleri doğrultusunda maddelerin kapsam geçerliği her bir madde için olumlu yanıt veren uzman sayısı toplamının toplam uzman sayısına oranının bir eksiği şeklinde hesaplanmış ve maddeler için kapsam geçerliliği oranı 0,80 olarak belirlenmiştir (Veneziano ve Hooper, 1997; akt. Yurdagül, 2005). Elde edilen kapsam geçerlik oranları hesaplamaları doğrultusunda ölçekten madde çıkartılmamıştır, ancak ölçekte yer alan "Araştırma için uygun veri toplama araçlarını geliştirebilir veya ölçeğin uyarlamasını ölçek geliştirme ve uyarlama süreçlerini dikkate alarak yürütebilirim" ifadesi "Araştırma için uygun veri toplama araçlarını geliştirebilir veya uyarlamasını yapabilirim" ve ölçekte yer alan diğer bir madde olan "Analiz sonucu elde ettiğim program çıktlarında yer alan istatistikleri sembol ve sayıları tablo haline getirerek yorumlayabilirim" ifadesi "Analiz sonucu elde ettiğim program çıktılarını tablo haline getirerek yorumlayabilirim" şeklinde değiştirilmiştir.

\section{Bulgular ve Yorumlar}

\section{Açımlayıcı Faktör Analizine Illişkin Bulgular}

Hazırlanan 48 maddelik deneme formunun öğretmenlere uygulanmasının ardından ölçeğin yapı geçerliğinin belirlenmesi için açımlayıcı faktör analizi yapılmıştr. Açımlayıcı faktör analizi sonunda, madde toplam korelasyon değeri 0.40 ve üzerindeki maddeler ölçekte kalırken 0,40 değerinin altında olan maddeler ve binişik durumuda olan maddeler ölçekten çıkarılmıştr. Yapılan analiz sonucu 37 maddenin faktör yük değerinin 0.40 ve üzerinde olduğu tespit edilmiş, ancak on bir $(6,7,24,10,17,18,31,32,46,38$ ve 44) maddenin 0.40 eşik değerinin alttnda kaldığı ve bazı maddelerin binişik olduğu tespit edildiğinden dolayı bu maddeler ölçekten çıkarılmıştır. 0.40 değerinin altında olan maddeler ölçekten çıkarıldıktan sonra ölçekteki maddelere yeniden madde sıra numarası verilerek maddeler yeniden numaralandırılmıştr. Ölçekte bulunan ve madde toplam korelasyon değeri 0.40 ve üzerinde olan tüm maddelere tekrar faktör analizi yapılmış ve ölçeğin KMO değeri ile Bartlett kürsellik testi sonuçları hesaplanmıştır. Açımlayıcı faktör analizi sonucu ölçeğin KMO değerinin 0,96 olduğu belirlenmiştir. KMO değeri, dağılımın faktör analizi için yeterli olup olmadığını test etmek amacıyla kullanılmakta olup, KMO değeri için 0.80 ve 0.90 aralığı çok iyi, 0.90 ve üzeri değerler ise mükemmel olarak nitelendirilmesine ek olarak KMO değerinin 1'e yakın bir değer alması halinde çalışma grubunun sayısının yeterli olduğu kanısına varılabileceği ifade edilmektedir (Büyüköztürk, 2007; Fraenkel ve Wallen, 2000; Kline, 1994). Bartlett küresellik testi sonucu $[\chi 2=7838.972 / s d=666 ; p<0.000]$ olarak hesaplanmışttr ve Bartlet küresellik testi sonucunun istatistiksel olarak anlamlı olması ölçüm yapılan değişkenin evrende çok değişkenli olduğunu göstermektedir (Thompson, 2004). Sonuç olarak bu çalışmada elde edilen KMO değeri mükemmel anlama gelen 0.96 şeklinde, Bartlett küresellik testi sonucu da anlamlı [ $\chi 2=7838.972 / \mathrm{sd}=666 ; p<0.000]$ olarak hesaplanmıştır. Çalışma da gerçekleştirilen bu analizlerin bir neticesi olarak açımlayıcı faktör analizinin yapılabileceğine karar verilmiştir. Faktör analizinde öz değeri 1 ya da 1 'den daha büyük olan faktörler kabul edilmektedir (Büyüköztürk, 2002). Bu çalışmada özdeğer 1.00 olarak alınmış ve öz değeri 1.00'dan büyük alt faktör olduğu belirlenmiştir. Illgili faktörlerin isimlendirmesi yapılırken ilgili faktör altında toplanan maddelerin ölçtüğü ortak özellik baz alınmıştır. Ölçek maddelerinin faktörleri incelendiğinde birinci faktörde (S34,S33,S37,S32,S35,S31 ve S36) maddelerinin bulunduğu ve bu faktörün bilimsel araştırmanın raporlaşttrma boyutuyla ilgili maddeleri içerdiği, ikinci faktörde (S27,S26,S25,S30,S28 ve S29) maddelerinin bulunduğu ve bu faktöründe bilimsel araştrmanın veri analizi ile ilgili maddeleri içerdiği, üçüncü faktörde (S9,S12,S11,S8,S10,S13 ve S7) maddelerinin bulunduğu ve bu faktöründe bilimsel araştırmanın literatür tarama boyutu ile ilgili maddeleri içerdiği, dördüncü faktörde (S22,S23,S20,S19,S21 ve S24) maddelerinin bulunduğu ve bu faktöründe bilimsel araştrrmanın yöntem boyutu ile ilgili maddeleri içerdiği, beşinci faktörde (S16,S17,S18,S15 ve S14) maddelerinin bulunduğu ve bu maddelerinde bilimsel araştırmanın hipotez(ler)i belirleme boyutu ile ilgili maddeleri içerdiği son olarak altınc faktörde (S1,S2,S4,S3,S6 ve S5) maddelerin bulunduğu ve bu maddelerinde bilimsel araştırmanın problemi tanımlama boyutuyla ilişkili olduğu ve ilgili maddelerin ilgili faktörler altında bulunmasına karar verilmiştir. Bu amaçla ölçeğe uygulanan döndürülmüş bi- 
leşenler analizi sonuçlarına ilişkin olarak elde edilen faktörler ve bu faktörlerde yeralan maddelere ilişkin faktör yükleri Tablo 2'de belirtilmiştir.

Tablo 2. Ölçeğin Döndürülmüş Temel Bileşenler Analiz Yöntemindeki Maddelerin Faktör Yükleri

\begin{tabular}{|c|c|c|c|c|c|c|c|c|c|c|c|}
\hline Madde & Raporlaştırma & Madde & $\begin{array}{c}\text { Veri } \\
\text { Analizi }\end{array}$ & Madde & $\begin{array}{c}\text { Literatür } \\
\text { Tarama }\end{array}$ & Madde & Yöntem & Madde & $\begin{array}{l}\text { Hiptez(ler) } \\
\text { Belirleme }\end{array}$ & Madde & $\begin{array}{c}\text { Problemi } \\
\text { Tanımlama }\end{array}$ \\
\hline S34 & 708 & S27 & 632 & S9 & ,754 & S22 & ,717 & S16 & 701 & S1 & 848 \\
\hline S33 & 708 & S26 & 618 & S12 & 684 & $\mathrm{S} 23$ & 701 & S17 & 696 & $\mathrm{S} 2$ & ,806 \\
\hline S37 & 704 & S25 & ,589 & S11 & ,635 & S20 & 673 & S18 & 691 & S4 & ,572 \\
\hline S32 & 703 & S30 & ,587 & S8 & ,623 & S19 & ,627 & S15 & ,573 & S3 & ,570 \\
\hline S35 & 680 & S28 & ,584 & S10 & 609 & $\mathrm{~S} 21$ & 623 & S14 & ,560 & S6 & ,539 \\
\hline S31 & 679 & S29 & ,467 & S13 & 608 & S24 & 621 & & & S5 & ,478 \\
\hline S36 & 675 & & & S7 & ,604 & & & & & & \\
\hline
\end{tabular}

Varyans \% 19.19

$\% 1239$

Tablo 2'deki bulgular doğrultusunda ölçeğe ilişkin birinci faktörde "Raporlaşttrma" boyutunda yer alan maddelerin yüklerinin 0.708 ile 0.675 arasında değiştiği, ikinci faktördeki "Veri Analizi" boyutunda bulunan maddelerin faktör yük değerlerimin 0.632 ile 0.467 arasında değiştiği, üçüncü faktördeki "Literatür Tarama" boyutunda ki maddelerin faktör yük değerlerinin 0.754 ile 0.604 arasında değiştiği, dördüncü faktördeki "Yöntem" boyutunda ki maddelerin faktör yük değerlerinin .717 ile 621 arasında değiştiği, beşinci faktördeki "Hipotez(ler)i belirleme" boyutunda bulunan maddelerin faktör yük değerlerinin .701 ile 560 arasında değiştiği ve son olarak altıncı faktördeki "Problemi Tanımlama" boyutunda yer alan maddelerin faktör yük değerlerinin 0.848 ile 0.478 arasında değiştiği görülmektedir. Diğer taraftan, birinci faktörün açıkladığı varyans oranı \%19.19, ikinci faktörün açıkladığı varyans oranı \%12.39, üçüncü faktörün açıkladığı varyans oranı \%11.32, dördüncü faktörün açıkladığı varyans oranı \%9.74, beşinci faktörün açıkladığı varyans oranı \% 9.30 ve son olarak altıncı faktörün açıkladığı varyans oranı ise \%2.99 olarak bulunmuştur. Ayrıca ölçeğin toplam açıkladığı varyans oranı ise \% 64.95 olarak hesaplanmıştır. Faktör analizinde \% 40 ile \% 60 arasında değişen varyans oranları ideal olarak kabul edilmektedir (Kline, 1994). Belirlenen alt faktöre ilişkin korelasyon değerleri Tablo 3'te belirtilmiştir.

Tablo 3. Ölçeğin Faktörleri Arasındaki Korelasyon Değerleri

\begin{tabular}{lcccccccc}
\hline Faktörler & $\bar{X}$ & Ss & Fak1 & Fak2 & Fak3 & Fak4 & Fak5 & Fak6 \\
\hline Raporlaşttrma & 3.939 & .683 & 1 & & & & & \\
Veri Analizi & 3.847 & .649 & $.838^{* *}$ & 1 & & & & \\
Literatür Tarama & 3.852 & .688 & $.677^{* *}$ & $.671^{* *}$ & 1 & & & \\
Yöntem & 3.954 & .665 & $.737^{* *}$ & $.714^{* *}$ & $652^{* *}$ & 1 & & \\
Hipotez (ler)i Belirleme & 4.015 & .715 & $.683^{* *}$ & $.671^{* *}$ & $.714^{* *}$ & $.694^{* *}$ & 1 & \\
Problemi Tanımlama & 3.937 & .682 & $.529^{* *}$ & $.557^{* *}$ & $.640^{* *}$ & $.525^{* *}$ & $.612^{* *}$ & 1 \\
\hline
\end{tabular}

** $p<0.01$

Tablo 3'te verilen öğretmenlerin bilimsel araştırmanın basamaklarına yönelik öz-yeterlilik algı ölçeğinin faktörleri arasındaki ilişkiye bakıldığında, ölçeğin faktörleri arasında pozitif ve doğrusal bir ilişki $(p<0.01)$ olduğu görülmektedir.

\section{Geçerlik ve Güvenirliğe iliş̧kin Bulgular}

Ölçeğin madde ayırt ediciliğini belirlemek için madde-toplam korelasyonu ve \% 27'lik alt-üst grup karşılaştırmaları yapılmıştır. Alt ve üst grup verileri ile ilgili maddenin o madde ile ölçülmek istenen özelliğe sahip olanlar ile olmayanları ayırt edip edemediğinin bir ölçüsü olarak ifade edilmektedir (Demirel, 2003). Ölçeğin iç geçerliliğinin tespiti için bağımsız gruplar-t test uygulanmıştır. Bu uygulamda ilk olarak test puanları küçükten büyüğe doğru sıralanmış ve grubun $\% 27^{\prime}$ lik alt ve üst kısmı hesaplanmıştır. \%27'lik alt kııımda kalan 86 ve \% $27^{\prime}$ lik üst kııımda kalan 86 öğretmenin aldığı toplam puanlara ait t-testi sonuçları Tablo 4'te karşılaştırılmıştır. 
Tablo 4. Ölçeğin Madde Ayırtediciliğine iliş̧kin t-Testi Sonuçları

\begin{tabular}{|c|c|c|c|c|c|c|c|c|c|c|c|}
\hline Boyut & Madde & Grup & $\bar{X}$ & Ss & $\mathbf{t}$ & Boyut & Madde & Grup & $\bar{X}$ & Ss & $\mathbf{t}$ \\
\hline & \multirow[t]{2}{*}{ S34 } & Üst $_{\% 27}$ & 4.20 & .717 & $8.333^{* *}$ & & S27 & Üst $_{\% 27}$ & 4.20 & .683 & $8.294 * *$ \\
\hline & & $\mathrm{Alt}_{\% 27}$ & 3.22 & .817 & & & & Alt $_{\% 27}$ & 3.23 & .836 & \\
\hline & \multirow[t]{2}{*}{ S33 } & Üst $_{\% 27}$ & 4.33 & .727 & $11.012^{* *}$ & & S26 & Üst $_{\% 27}$ & 4.17 & .706 & $9.539 * *$ \\
\hline & & $\mathrm{Alt}_{\% 27}$ & 3.08 & .755 & & & & $\mathrm{Alt}_{\% 27}$ & 3.13 & .732 & \\
\hline & \multirow[t]{2}{*}{ S37 } & Üst $_{\% 27}$ & 4.43 & .678 & $9.201 * *$ & & S25 & Üst $_{\% 27}$ & 4.13 & .809 & $8.118^{* *}$ \\
\hline & & $\mathrm{Alt}_{\% 27}$ & 3.31 & .898 & & & & Alt $_{\% 27}$ & 3.16 & .749 & \\
\hline \multirow[t]{14}{*}{ Raporlaştırma } & \multirow[t]{2}{*}{ S32 } & Üst $_{\% 27}$ & 4.23 & .762 & $8.931^{* *}$ & $\begin{array}{c}\text { Veri } \\
\text { Analizi }\end{array}$ & S30 & Üst $_{\% 27}$ & 4.06 & .831 & $7.642^{* *}$ \\
\hline & & Alt $_{\% 27}$ & 3.19 & .775 & & & & Alt $_{\% 27}$ & 3.13 & .764 & \\
\hline & \multirow[t]{2}{*}{ S31 } & Üst $_{\% 27}$ & 4.27 & .773 & $9.477^{* *}$ & & $\mathrm{~S} 28$ & Üst $_{\% 27}$ & 4.33 & .727 & $8.425^{* *}$ \\
\hline & & $\mathrm{Alt}_{\% 27}$ & 3.17 & .739 & & & & Alt $_{\% 27}$ & 3.31 & .844 & \\
\hline & \multirow[t]{2}{*}{ S36 } & Üst $_{\% 27}$ & 4.37 & .669 & $9.820^{* *}$ & & S29 & Üst $_{\% 27}$ & 4.21 & .856 & $7.396 * *$ \\
\hline & & $\mathrm{Alt}_{\% 27}$ & 3.26 & .814 & & & & $\mathrm{Alt}_{\% 27}$ & 3.24 & .735 & \\
\hline & \multirow[t]{2}{*}{ S35 } & Üst $_{\% 27}$ & 4.28 & .746 & $7.843 * *$ & & & & & & \\
\hline & & $\mathrm{Alt}_{\% 27}$ & 3.35 & .808 & & & & & & & \\
\hline & \multirow[t]{2}{*}{ S9 } & Üst $_{\% 27}$ & 4.08 & .829 & $7.767^{* *}$ & & S22 & Üst $_{\% 27}$ & 4.22 & .676 & $7.597^{* *}$ \\
\hline & & Alt $_{\% 27}$ & 3.07 & .878 & & & & $\mathrm{Alt}_{\% 27}$ & 3.35 & .823 & \\
\hline & \multirow[t]{2}{*}{ S12 } & Üst $_{\% 27}$ & 3.86 & .922 & $6.661^{* *}$ & & S23 & Üst $_{\% 27}$ & 4.20 & .648 & $8.395^{* *}$ \\
\hline & & $\mathrm{Alt}_{\% 27}$ & 2.99 & .790 & & & & Alt $_{\% 27}$ & 3.26 & .814 & \\
\hline & \multirow[t]{2}{*}{ S11 } & Üst $_{\% 27}$ & 4.35 & .716 & $8.914^{* *}$ & & S20 & Üst $_{\% 27}$ & 4.38 & .689 & $8.278^{* *}$ \\
\hline & & Alt $_{0 / 27}$ & 3.26 & .884 & & & & Alt $_{\% 27}$ & 3.38 & .883 & \\
\hline \multirow[t]{11}{*}{$\begin{array}{l}\text { Literatür } \\
\text { Tarama }\end{array}$} & \multirow[t]{2}{*}{ S8 } & Üst $_{\% 27}$ & 4.23 & .626 & $9.380 * *$ & Yöntem & S19 & Üst $_{\% 27}$ & 4.38 & .706 & $9.095^{* *}$ \\
\hline & & $\mathrm{Alt}_{\% 27}$ & 3.20 & .809 & & & & $\mathrm{Alt}_{\% 27}$ & 3.37 & .752 & \\
\hline & \multirow[t]{2}{*}{ S10 } & Üst $_{\% 27}$ & 4.31 & .724 & $8.443 * *$ & & S21 & Üst $_{\% 27}$ & 4.27 & .676 & $8.528^{* *}$ \\
\hline & & $\mathrm{Alt}_{\% 27}$ & 3.28 & .877 & & & & $\mathrm{Alt}_{\% 27}$ & 3.31 & .786 & \\
\hline & \multirow[t]{2}{*}{ S13 } & Üst $_{\% 27}$ & 4.07 & .764 & $8.873 * *$ & & S24 & Üst $_{\% 27}$ & 4.22 & .676 & $7.154^{* *}$ \\
\hline & & $\mathrm{Alt}_{\% 27}$ & 2.99 & .833 & & & & $\mathrm{Alt}_{\% 27}$ & 3.40 & .830 & \\
\hline & \multirow[t]{2}{*}{ S7 } & Üst $_{\% 27}$ & 4.23 & .680 & $8.716^{* *}$ & & & & & & \\
\hline & & Alt $_{\% 27}$ & 3.17 & .897 & & & & & & & \\
\hline & \multirow[t]{2}{*}{ S16 } & Üst $_{\% 27}$ & 4.41 & .692 & $7.918^{* *}$ & & S1 & Üst $_{\% 27}$ & 5.00 & .000 & $14.829 * *$ \\
\hline & & $\mathrm{Alt}_{\% 227}$ & 3.40 & .961 & & & & $\mathrm{Alt}_{\% 27}$ & 3.37 & 1.018 & \\
\hline & S17 & Üst $_{\% 27}$ & 4.24 & .839 & $7.278^{* *}$ & & S2 & Üst $_{\% 27}$ & 4.65 & .479 & $9.915^{* *}$ \\
\hline \multirow[t]{9}{*}{$\begin{array}{l}\text { Hiptez(ler)i } \\
\text { Belirleme }\end{array}$} & & Alt $_{\% 27}$ & 3.23 & .978 & & $\begin{array}{c}\text { Problemi } \\
\text { Tanımlama }\end{array}$ & & $\mathrm{Alt}_{\% 27}$ & 3.44 & 1.024 & \\
\hline & \multirow[t]{2}{*}{ S18 } & Üst $_{\% 27}$ & 4.23 & .807 & $6.510 * *$ & & S4 & Üst $_{\% 27}$ & 4.26 & .636 & $7.369 * *$ \\
\hline & & $\mathrm{Alt}_{\% 27}$ & 3.36 & .944 & & & & Alt $_{\% 27}$ & 3.34 & .965 & \\
\hline & \multirow[t]{2}{*}{ S15 } & Üst $_{\% 27}$ & 4.31 & .656 & $8.121 * *$ & & S3 & Üst $_{\% 27}$ & 4.36 & .766 & $9.944 * *$ \\
\hline & & $\mathrm{Alt}_{\% 27}$ & 3.34 & .902 & & & & $\mathrm{Alt}_{\% 27}$ & 3.05 & .957 & \\
\hline & \multirow[t]{4}{*}{ S14 } & Üst $_{\% 27}$ & 4.48 & .646 & $8.967 * *$ & & S6 & Üst $_{\% 27}$ & 4.59 & .517 & $10.222^{* *}$ \\
\hline & & Alt $_{\% 27}$ & 3.36 & .957 & & & & Alt $_{\% 27}$ & 3.35 & 1.003 & \\
\hline & & & & & & & S5 & Üst $_{\% 27}$ & 4.35 & .665 & $8.402^{* *}$ \\
\hline & & & & & & & & $\mathrm{Alt}_{\% 27}$ & 3.33 & .913 & \\
\hline
\end{tabular}

Tablo 4'te elde edilen veriler incelendiğinde, madde toplam puanlarında üst grubun ortalamasının daha yüksek ( $\bar{X}$ $=4.29$ ) olduğu görülmektedir. Bu durum üst grup lehine istatistiksel olarak anlamlı bir fark olduğunu ifade edilmekle birlikte maddelerin kendi içinde ayırt ediciliğinin yüksek olduğunu ve iç geçerliliğe sahip olduğunu göstermektedir. Ölçeğin güvenirliği Cronbach Alpha güvenilirlik katsayısı ile hesaplanmıştr. Cronbach Alpha iç tutarlılık katsayısı 0.95 olarak bulunmuş ve bu değerin yüksek bir güvenirlik katsayısı olduğu belirlenmiştir. İgili alan yazında güvenirlik çalışmalarında 0.60 ile 0.70 düzeyindeki güvenirlik katsayılarının yeterli olduğu ifade edilmektedir (Cronbach, 1990). Ölçeğinin faktörlerine ilişkin güvenirlik katsayıları ise Tablo 5'te sunulmuştur. 
Tablo 5. Ölçeğinin Faktörlerinin Cronbach Alpha Güvenirlik Katsayıları

\begin{tabular}{lcc}
\hline \multicolumn{1}{c}{ Faktör } & Madde No & Güvenirlik \\
\hline Raporlaşttrma & $31,32,33,34,35,36,37$ & 0.92 \\
Veri Analizi & $25,26,27,28,29,30$ & 0.81 \\
Literatür Tarama & $7,8,9,10,11,12,13$, & 0.89 \\
Yöntem & $19,20,21,22,23,24$ & 0.89 \\
Hipotez(ler)i Belirleme & $14,15,16,17,18$ & 0.88 \\
Problemi Tanımlama & $1,2,3,4,5,6$ & 0.86 \\
\hline
\end{tabular}

Tablo 5 incelendiğinde faktörlerin güvenirlik katsayılarının 0.92 ile 0.81 arasında değiştiği ve güvenirlik katsayısı değerinin en az 0.70 olması gerektiği (Kline, 1994; Peers, 1996; Gorsuch, 1983) dikkate alındığında, ölçeğin tümünün ve her bir faktörünün güvenilir değerlere sahip oldukları belirlenmiştir. Ölçeğin faktörlerine iliş̧in korelasyon değerleri Tablo 6'da gösterilmiştir.

\section{Tablo 6. Ölçeğin Faktörlerinin Illgili Maddelerle Olan Korelâsyon Değerleri}

\begin{tabular}{|c|c|c|}
\hline Madde No & Faktör 1. Raporlaştırma & $\mathbf{r}$ \\
\hline 31 & Analiz sonucu elde ettiğim program çıktılarında yer alan tabloları hipotez(ler) bağlamında yorumlayabilirim & 0.71 \\
\hline 32 & Analiz sonucu elde ettiğim program çıktılarını tablolaştırarak yorumlayabilirim & 0.69 \\
\hline 33 & Raporlaştırma sürecini hipotez(ler)in sınanma durumuna göre yazabilirim & 0.76 \\
\hline 34 & Raporlaştırılma sürecini araştırmayı bir bütün olarak ele alarak tamamlayabilirim & 0.73 \\
\hline 35 & Raporlaştırma sürecini güncel araştırma bulguları ile destekleyebilirim & 0.70 \\
\hline 36 & Raporlaştırılma sürecinde çalışmadan elde ettiğim bulgulardan yola çıkarak önerilerde bulunabilirim & 0.72 \\
\hline 37 & Raporlaştırma sürecinde çalışma bulgularını tartışarak okuyucuya sunabilirim & 0.72 \\
\hline Madde No & Faktör 2. Veri Analizi & $\mathbf{r}$ \\
\hline 25 & Veri analizinde kullanacağım istatistiksel analiz tekniklerinin varsayımlarını test edebilirim. & 0.67 \\
\hline 26 & Verileri uygulayacağım analize hazır hale getirebilirim. & 0.73 \\
\hline 27 & Hipotez(ler)i sınayabilecek uygun veri analiz tekniklerini (Nice/Nitel) uygulayabilirim & 0.68 \\
\hline 28 & Veri analizi aşamasında elde ettiğim sayısal ifadeleri istatistiksel olarak yorumlayabilirim & 0.67 \\
\hline 29 & $\begin{array}{l}\text { Veriler üzerinde betimleyici istatistikî işlemleri (frekans, yüzde, aritmetik ortalama, standart sapma, vb.) } \\
\text { işlemlerini yapabilirim }\end{array}$ & 0.54 \\
\hline 30 & Nitel ve Nicel veri analiz programlarını kullanabilirim & 0.65 \\
\hline Madde No & Faktör 3. Literatür Tarama & r \\
\hline 7 & Literatürü problem durumu bağlamında irdeleyebilirim & 0.68 \\
\hline 8 & Literatür taraması ile problem durumunun özgünlüğünü ortaya koyabilirim & 0.69 \\
\hline 9 & Literatür taramasının amacı ve gerekçesi hakkında yeterli bilgiye sahibim & 0.67 \\
\hline 10 & Uygun veri tabanlarından anahtar kelimeler yardımı ile ilgili literatürü tarayabilirim & 0.72 \\
\hline 11 & Literatür taraması ile problem durumunun gerekçelerini ortaya koyabilirim & 0.69 \\
\hline 12 & Literatür taraması için ulusal ve uluslararası veri tabanlarına ulaşabilirim & 0.60 \\
\hline 13 & Literatür taraması sonucu elde ettiğim bilgilerin aktarımını bilimsel kurallara göre yapabilirim & 0.67 \\
\hline Madde No & Faktör 4. Yöntem & $\mathbf{r}$ \\
\hline 19 & Hipotezleri sınayabileceğim uygun yöntemi belirleyebilirim & 0.70 \\
\hline 20 & Kullanacağım yöntemin sınırlılıklarını belirleyebilirim & 0.69 \\
\hline 21 & Çalışma grubunu (Evren/Örneklem) tespit etmek için uygun yöntemi belirleyebilirim & 0.69 \\
\hline 22 & Araştırma için uygun veri toplama araçlarının seçimini yapabilirim & 0.66 \\
\hline 23 & Araştırma için uygun veri toplama araçlarını geliştirebilir veya uyarlamasını yapabilirim & 0.68 \\
\hline 24 & Araştırmada kullanacağım veri toplama araçlarının geçerlilik ve güvenirlik çalışmalarını yapabilirim & 0.63 \\
\hline Madde No & Faktör 5. Hipotez(ler)i Belirleme & $r$ \\
\hline 14 & Hipotez(ler)in rasyonel, açık ve anlaşılır olmasına dikkat ederim & 0.70 \\
\hline 15 & Hipotez(ler)i araştırmanın diğer basamaklarını yürütmek için rehber olarak kullanabilirim & 0.71 \\
\hline 16 & Hipotez(ler)in tahmin, deney ve gözlemlere açık olmasına dikkat ederim & 0.71 \\
\hline 17 & Hipotez(ler)in değer yargılarından ve genel yargılardan arındırılmış olmasına dikkat ederim & 0.69 \\
\hline 18 & Hipotez(ler)in sınanabilir olmasına dikkat ederim & 0.67 \\
\hline Madde No & Faktör 6. Problemi Tanımlama & $\mathbf{r}$ \\
\hline 1 & Problem durumunu çevreyi gözlemleyerek belirleyebilirim & 0.50 \\
\hline 2 & Problem durumunu belirledikten sonra araştırmayı bu doğrultuda sürdürebilirim & 0.57 \\
\hline
\end{tabular}


$3 \quad$ Problem durumunu tanımlama sürecini bireysel olarak yürütebilirim 0.59

$4 \quad$ Problem durumunu tanımlarken ilgili alandaki bir boşluğu dolduracak olmasını dikkate alırım 0.55

5 Problem durumunun özgün değerinin olup olmadığını belirleyebilirim 0.60

6 Problem durumunu toplumun önceliklerini ve ihtiyaçlarını dikkate alarak belirleyebilirim 0.67

Tablo 6 incelendiğinde, ölçek puanlarının aritmetik ortalaması 3.92, standart sapmasının ortalaması ise 0.57 olduğu belirlenmiştir. Madde toplam analizi sonucunda ölçekte yer alan tüm maddeler ile toplam puanlar arasında istatistiksel olarak anlamlı fark bulunduğu belirlenmiştir $(p<0.01)$. Katsayılar incelendiğinde, birinci faktör için 0,69 ile 0,72; ikinci faktör için 0,54 ile 0,73; üçüncü faktör için 0,60 ile 0,72; dördüncü faktör için 0,63 ile 0,70; beşinci faktör için 0.67 ile 0.71 ve altıncı faktör için 0.50 ile 0.67 arasında değiştiği belirlenmiştir. Ölçekte yer alan her bir maddeden elde edilen puan ile maddenin bulunduğu faktörden elde edilen puan arasında korelasyon bulunması, ölçekte yer alan her bir maddenin, faktörün genel amacına hizmet etme düzeyinin anlaşılması açısından bir kriter olarak kullanılmaktadır (Balcı, 2009). Bu sonuca göre ölçekte yeralan her bir madde ve faktörün, ölçeğin geneli ile ölçülmek istenen özelliği ölçebilme amacına istatistiksel açıdan anlamlı düzeyde karşıladığı ve her bir maddenin istenilen seviyede ayırt edici olduğu belirlenmiştir.

\section{Birinci Düzey Doğrulayıcı Faktör Analizine ílişsin Bulgular}

Elde edilen modelin doğruluğunu belirlemek amacıyla 238 kişilik farklı bir örneklem grubundan elde edilen veriler üzerinde birinci düzey doğrulayıcı faktör analizi yapılmadan önce analizin varsayımları olan normal dağılım, doğrusallık, aykırı değerlerin çıkarılması ve boş değerlerin belirlenmesi işlemleri gerçekleştirilmiştir. Veri girişi esnasında eksik veriler kontrol edilmiş ve eksik veri bulunmadığı tespit edilerek veri girişi sağlanmıştır. Ardından artık değerlerin belirlenmesi için, standartlaştrılmış artk değerleri incelenmiş ve 0.05 anlamlılık düzeyinde t değerlerinin $-1,96$ ve $+1,96$ aralığında yer alıp almadıkları araştırılmış ve verilerde artı değer bulunmadığı tespit edilmiştir. Son olarak çalışmada 37 maddeden oluşan verilerin normal dağılıma sahip olup olmadığını belirlemek için Lisrel programı ile çok değişkenli Mardia normallik testi yapılmıştr. Bu test sonucunda maddelere ilişkin çok değişkenli basıklık (relative multivariate kurtosis) değeri 1.645 bulunmuştur. Çok değişkenli normallik için göreli çok değişkenli basıklık değerinin <2 olması dağılımın normal olduğunu göstermektedir (Kline, 1998). Elde edilen bu sonuçlar ışığında veri setinin uygulama için yeterli ön koşullara sahip olduğu sonucu elde edilmiştir. Birinci düzey doğrulayıcı faktör analizinde ölçek maddeleri tarafindan yapılandırıldığı düşünülen birden fazla gizil değişkenin bir başka gizil değişken tarafindan açıklandığı varsayılır ve bu varsayımın veri setine uygunluğu test edilmektedir (Jöroskog ve Sörbom, 1993; Schumacher ve Lomax, 1996; Kline, 2005; Şimşek, 2007). Birinci düzey doğrulayıcı faktör analizi sonucunda uyum iyiliği değerleri incelendiğinde, $\chi 2$ (sd, $\mathrm{N})=(1500.35,614 ; 238), \chi 2 / \mathrm{sd}=2.443, \mathrm{RMSEA}=0.078, \mathrm{~S}-\mathrm{RMR}=0.065, \mathrm{AGFI}=0.71, \mathrm{NFI}=0.94, \mathrm{NNFI}=0.96, \mathrm{CFI}=0.97$ ve $\mathrm{IFI}=$ 0.97 olarak bulunmuştur. Birinci düzey doğrulayıcı faktör analizi sonucu (S2 ile S1, S20 ile S19, S18 ile S17 ve S23 ile S22) maddeleri arasında modifikasyon işlemi yapılarak elde edilen uyum iyiliği değerleri incelendiğinde; $\chi 2(\mathrm{sd}, \mathrm{N})=(1327.63$, $610 ; 238), \chi 2 / s d=2.176, \mathrm{RMSEA}=0.070, \mathrm{~S}-\mathrm{RMR}=0.065, \mathrm{AGFI}=0.71, \mathrm{NFI}=0.94, \mathrm{NNFI}=0.96, \mathrm{CFI}=0.97$ ve $\mathrm{IFI}=0.97$ olarak bulunmuştur. Elde edilen verilere göre modelin ölçek gözlenen değerleri kabul edilebilir uyum gösterdiği belirlenmiştir. Diğer bir ifade ile elde edilen bu model, veriler tarafindan faktörlerin doğrulandığını ortaya koymaktadır. Ölçeğin birinci düzey doğrulayıcı faktör analiz sonucu elde edilen model ve faktör-madde ilişkisine dair t değerleri Şekil 1'de verilmiştir.

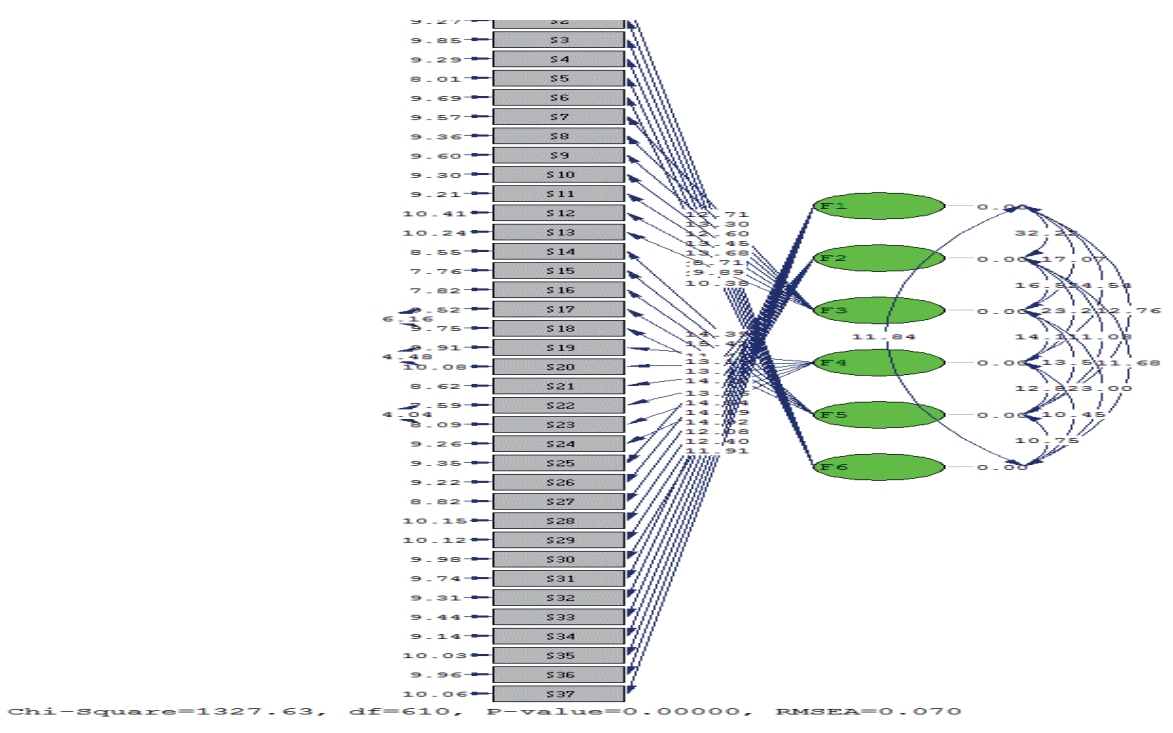


Şekil 1 incelendiğinde, doğrulayıc faktör analizinin bir sonucunda $\chi 2 / s d$ oranı 2.443 ( $\chi 2 / s d=1327.63 / 610$ ) olarak hesaplanmıştr. İlgili alanyazında ki-kare uyum iyiliği ile serbestlik derecesi arasındaki oranın en fazla 3-4 veya bu oranlardan düşük olmasının gerektiği ifade edilmektedir (Kline, 2005). $\chi 2 /$ sd oranının 3 'ten düşük olması faktör yapısının uyumlu olduğunu göstermektedir. Buna ek olarak RMSEA değeri de 0.070 olarak hesaplanmış ve bu değer kabul edilebilir uyum iyiliği olarak ifade edilmektedir (Brown, 2006).

Elde edilen diğer uyum indeksleri incelendiğinde, CFI değeri 0.97 olarak hesaplanmışttr. CFI değerinin 0.95'e eşit veya bu değerden büyük olması mükemmel uyum olarak ifade edilmektedir (Thompson, 2004). Çalışmada NFI değeri 0.95 olarak, NNFI değeri ise 0.96 olarak hesaplanmışttr. NFI ve NNFI değerlerinin de 0.95 'e eşit veya bu değerden büyük olması mükemmel uyum iyiliğine işaret etmekle birlikte (Sümer, 2000). GFI 0.75 ve AGFI'da 0.71 olarak saptanmış olup, bu değerlerin uyum için yeterli olduğu ifade edilebilir. GFI ve AGFI indekslerinin 1'e eşit olması mükemmel uyuma işaret etmektedir (Hooper, Coughlan ve Mullen, 2008). Birinci düzey doğrulayıcı factor analizi sonucu elde edilen sonuçlar incelendiğinde, ölçeğin mükemmel ve kabul edilebilir uyum değerlerine sahip olduğu belirlenmiştir.

\section{İkinci Düzey Doğrulayıcı Faktör Analizine ilişkin Bulgular}

Ölçeğin birinci düzey doğrulayıcı faktör analizi ile elde edilen "Raporlaştırma”, "Veri Analizi", "Literatür Tarama", "Yöntem", "Hipotez(ler)i Belirleme" ve "Problemi Tanımlama" boyutlarının bir araya gelerek bir üst kavramı temsil ettiğini belirtmek amacıyla ikinci düzey doğrulayıc faktör analizi yapılmıştr. Bu model için temel olarak, birinci düzey doğrulayıcı faktör analizinde elde edilen gizil değişkenler arasındaki ilişkiler baz alınmıştır. 6 gizil ve 37 gösterge değişken ile test edilen birinci düzey doğrulayıcı yapıya ikinci düzey öz yeterlilik gizil değişkeni eklenerek ikinci düzey faktör modelinin test edilmesi sonucu uyum iyiliği değerleri $\chi 2 / s d, N(1405.21, s d=619, N=238), R M S E A=0.073, S-R M R=0.062$, $\mathrm{GFI}=0.077, \mathrm{AGFI}=0.73, \mathrm{CFI}=0.97, \mathrm{NNFI}=0.97, \mathrm{IFI}=0.97, \mathrm{NFI}=0.95$ olarak bulunmuştur. Elde edilen bu değerler modelin veri uygunluğunun yeterli olduğunu göstermektedir. Ölçeğin ikinci düzey doğrulayıcı faktör analizinin bağlant diyagramı ve t-değerleri Şekil 2 'de sunulmuştur. t değerleri incelendiğinde $(p<0.01)$ düzeyinde anlamlı olduğu belirlenmiştir.

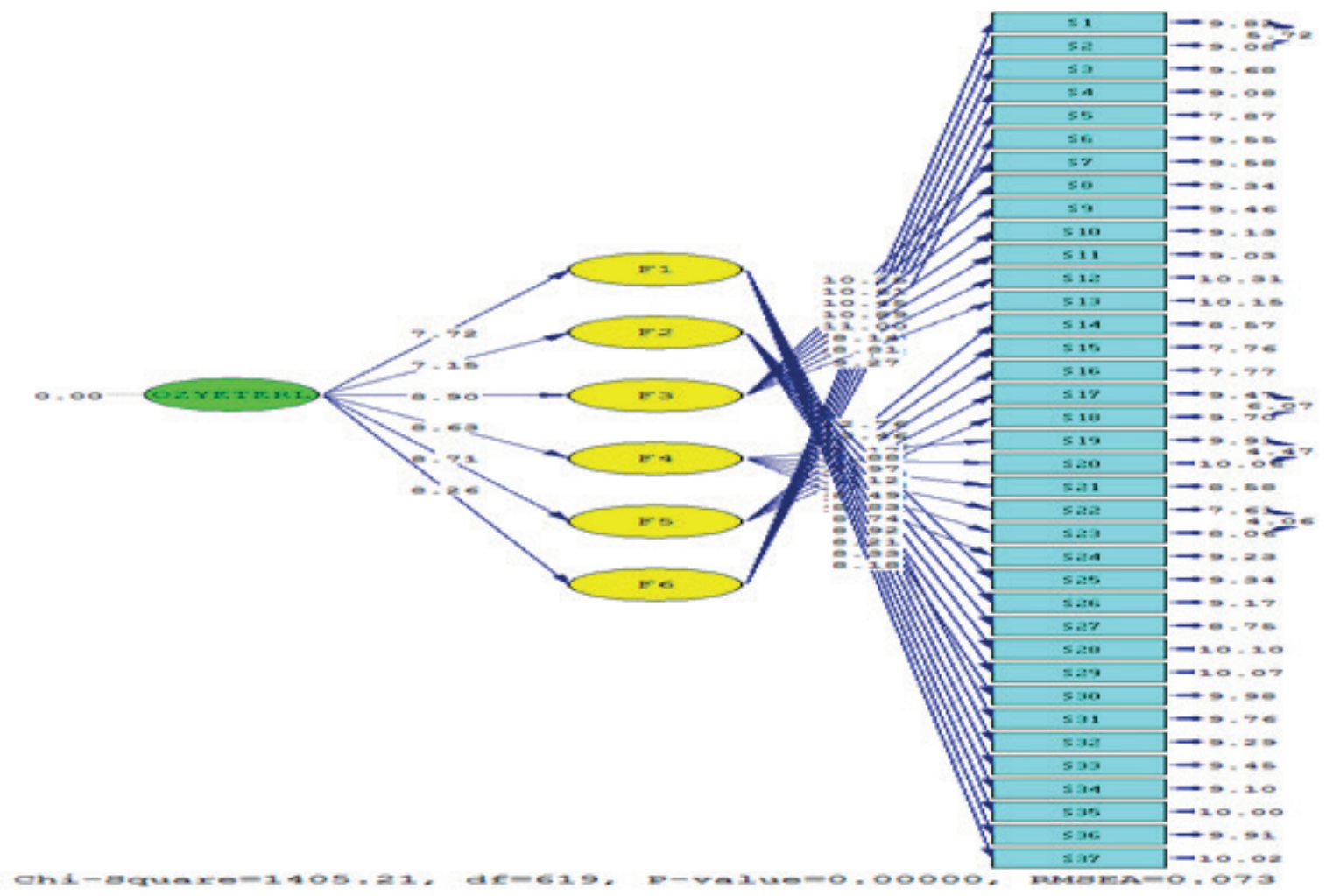

Şekil 2. İkinci Düzey Doğrulayııı Faktör Analizine ait t-testi Sonuçları

Modeldeki birinci düzey gizil değişkenler ile üst düzey (ikinci düzey) değişken olan "öz yeterlilik" arasındaki faktör yükleri $(\lambda x)$, t değerleri, ölçüm hataları (delta, $\delta$ ) ve ikinci düzey değişkenin birinci düzey değişkenlerdeki açıklama oranları $\left(R^{2}\right)$ Tablo 7'de verilmiştir. 
Tablo 7. Ölçeğin İkinci Düzey Doğrulayıcı Faktör Analizi $\lambda x, \delta, t$ ve $R^{2}$ Değerleri

\begin{tabular}{lccccc}
\hline İkinci Düzey Değişken & Birinci Düzey Değişsken & $\boldsymbol{\lambda} \mathbf{x}$ & $\begin{array}{c}\text { Skatsayısı } \\
\text { (Ölçüm Hatası) }\end{array}$ & $\mathbf{t}$ & $\mathbf{R}^{\mathbf{2}}$ \\
\hline \multirow{3}{*}{ Öz yeterlilik } & Raporlaştrma & 2.13 & 0.28 & 7.72 & 0.82 \\
& Veri Analizi & 2.12 & 0.30 & 7.15 & 0.81 \\
& Literatür Tarama & 1.40 & 0.16 & 8.90 & 0.66 \\
& Yöntem & 1.64 & 0.19 & 8.63 & 0.73 \\
& Hipotez (ler)i Belirleme & 1.00 & 0.11 & 8.71 & 0.50 \\
\hline
\end{tabular}

Tablo 7'deki veriler incelendiğinde, ikinci düzey öz yeterlilik gizil değişkeni ile birinci $(\lambda x=2.13 ; p<0.05 ; t=7.72)$, ikinci $(\lambda x=2.12 ; p<0.05 ; t=7.15)$, üçüncü $(\lambda x=1.40 ; p<0.05 ; t=8.90)$, dördüncü $(\lambda x=1.64 ; p<0.05 ; t=6.63)$, beşinci $(\lambda x=1.00$; $p<0.05 ; t=8.71)$ ve altnncı $(\lambda x=1.08 ; p<0.05 ; t=8.26)$ gizil değişkenler arasındaki yol katsayılarına ve $t$ değerlerine bakıldığında öz-yeterlilik ile tüm faktörler arasındaki ilişkinin pozitif yönde ve anlamlı olduğu belirlenmiştir. t değeri 1.96'nın üzerinde ise ( $p<0.05), 2.56$ 'nin üzerinde ise $(p<0.01)$ düzeyinde anlamlıdır (Schumacker ve Lomax, 2010).

Elimizdeki modelde tüm maddelere ait t değerlerinin ve modelde yeralan faktörlerin t değerlerinin anlamlı olması modelin kabul edilebilirliğinin bir koşuludur. i̇kinci düzey öz-yeterlilik gizil değişkeni tarafindan birinci düzey değişkenlerde açıklanan varyanslara bakıldığında, birinci düzey değişkenlerden en çok raporlaştırma $\left(R^{2}=0.82\right)$ değişkeninde, en az literatür tarama $\left(R^{2}=0.15\right)$ değişkeninde değişkenlik açıklanmıştır. Belirleme katsayısı olarak ifade edilen $\left(R^{2}\right)$ değeri de diğer uyum indeksleri gibi araştırmalarda belirtilmelidir. Açıklanan varyans olarak ifade edilen $\left(R^{2}\right)$ gösterge değişkenlerin gizil değişkenlerdeki gözlenen değişimlerin ne kadarını açıkladığını belirleyen katsayıdır (Kelloway, 1998). $\left(R^{2}\right)$ değeri $0.2^{\prime}$ nin altnnda ise zayıf, 0.2 ile 0.4 arasında ise orta güçlükte ve $0.4^{\prime}$ ün üzerinde ise güçlü olarak kabul edilmektedir https://www.american.edu/ctrl/ p.4.

\section{Sonuç ve Tartışma}

Bu çalışmada öğretmenlerin bilimsel araştırmalara yönelik öz yeterliliklerini belirlemek amacıyla bir ölçme aracı geliştirilmesi planlanmıştır. Bu amaç doğrultusunda 48 maddelik bir madde havuzu oluşturulduktan sonra elde edilen veriler öncelikle farklı branşlarda görev yapmaktan olan 338 öğretmene uygulanarak açımlayıcı faktör analizi yapılmıştr. Faktör analizi sonucu madde toplam korelasyon değeri 0,40 ve üzerinde olan maddeler ölçeğe dahil edilmiştir. Analizde sonucunda ölçekte bulunan 37 maddenin faktör yük değerinin 0,40 ve üzerinde olduğu tespit edilmiş, ancak on bir maddenin 0,40 değerinin altında kaldığı tespit edildiğinden dolayı bu maddeler ölçekten çıkarılmıştr. Maddeler ölçekten çıkarıldıktan sonra, ölçekteki maddeler yeniden numaralandırılmıştır. Elde edilen ve madde toplam korelasyon katsayısı 0,40 ve üzerinde olan tüm maddeler ikinci bir faktör analizi daha uygulanmış ve bu kez ölçeğin KMO değeri 0,96 olarak belirlenmiştir. KMO değeri, dağılımın faktör analizi için yeterli olup olmadığını test etmek amacıyla kullanılmakla birlikte KMO değeri için 0,90 ve üzeri değerler mükemmel olarak kabul edilmektedir (Büyüköztürk, 2007). Bartlett küresellik testi sonucuna göre ölçeğin bu değeri $[\chi 2=7838,972 / s d=666 ; p<0,000]$ olarak hesaplanmış ve Bartlett küresellik testinin anlamlı çıkması ölçüm yapılan değişkenin evren parametresinde çok değişkenli olduğunu ifade etmektedir (Thompson, 2004). Faktör analizinde öz değeri 1 ya da 1'den daha büyük olan faktörler önemli faktörler olarak kabul edilmektedir (Büyüköztürk, 2002). Bu araştırmada da özdeğer 1,00 olarak alınmış ve öz değeri 1.00'dan büyük alt faktör belirlenmiştir. Elde alt faktörlere ait yük değerleri incelendiğinde "Raporlaştırma" boyutunda yer alan maddelerin 0,708 ile 0,675 arasında değiştiği toplam varyansın \%19,19'unu açıkladığı, "Veri Analizi" boyutunda yer alan maddelerin 0,632 ile 0,467 arasında değiştiği ve toplam varyansın \%12,39'unu açıkladığı, "Literatür Tarama" boyutunda yer alan maddelerin 0,754 ile 0,604 arasında değiştiği ve toplam varyansın \%11,32'ni açıkladığı, "Yöntem" boyutunda yer alan maddelerin 0,717 ile 0,621 arasında değiştiği ve toplam varyansın \%9,74'nü açıkladığı, "Hipotez(ler) i Belirleme" boyutunda yer alan maddelerin 0,701 ile 0,560 arasında değiştiği ve toplam varyasın \%9,30'unu açıkladığı ve son olarak "Problemi Tanımlama" boyutunda yer alan maddelerin ise 0,848 ile 0,478 arasında değiştiği ve toplam varyansın \%2,99'unu açıkladığı ve faktörlerin toplam varyansın \%64,95'ini açıkladığı belirlenmiştir. Ölçeğin ayırt ediciliğinin belirlenmesi için ise \%27'lik alt ve $\% 27^{\prime}$ lik üst gruplar arasındaki ilişki t-testi ile incelenmiş ve gruplar arasında istatistiki açıdan anlamlı bir fark olduğu ve maddelerin kendi içinde ayırt ediciliğinin yüksek olduğunu ve iç geçerliliğe sahip olduğu sonucu elde edilmiştir. Farklı bir örneklem grubu ile yapılan birinci düzey doğrulayıcı faktör analizi sonucu elde edilen uyum iyiliği değerleri incelendiğinde; $\chi 2(s d, N)=(1327,63 ; 610 ; 238), \chi 2 / s d=2,176 ; R M S E A=0,070 ; S-R-$ $\mathrm{MR}=0,065 ; \mathrm{AGFI}=0,71 ; \mathrm{NFI}=0,94 ; \mathrm{NNFI}=0,96 ; \mathrm{CFI}=0,97$ ve $\mathrm{IFI}=0,97$ olarak bulunmuştur. Elde edilen verilere göre, modelin ölçek gözlenen değerleri, verinin kabul edilebilir uyum gösterdiğini ifade etmektedir. İkinci düzey doğrulayıcı faktör analizi sonucu elde edilen uyum iyiliği değerleri incelendiğinde $\chi 2 / s d, N(1405,21$; sd=619, N=238), RMSEA=0,073; 
$\mathrm{S}-\mathrm{RMR}=0,062 ; \mathrm{GFI}=0,077 ; \mathrm{AGFI}=0,73 ; \mathrm{CFI}=0,97 ; \mathrm{NNFI}=0,97 ; \mathrm{IFI}=0,97 ; \mathrm{NFI}=0,95$ olarak bulunmuştur. Modeldeki birinci düzey gizil değişkenler ile üst düzey (ikinci düzey) değişken olan "öz yeterlilik" arasındaki faktör yükleri ( $\lambda \mathrm{x})$, $\mathrm{t}$ değerleri, ölçüm hataları (delta, $\delta$ ) ve ikinci düzey değişkenin birinci düzey değişkenlerdeki açıklama oranları $\left(R^{2}\right)$ incelendiğinde, ikinci düzey öz yeterlilik gizil değişkeni ile birinci $(\lambda x=2,13 ; p<0,05 ; t=7,72)$, ikinci $(\lambda x=2,12 ; p<0,05 ; t=7,15)$, üçüncü $(\lambda x=1,40 ; p<0,05 ; t=8,90)$, dördüncü $(\lambda x=1,64 ; p<0,05 ; t=6,63)$, beşinci $(\lambda x=1,00 ; p<0,05 ; t=8,71)$ ve altncı $(\lambda x=1,08$; $p<0,05 ; t=8,26)$ gizil değişkenler arasındaki yol katsayılarına ve $t$ değerlerine bakıldığında öz-yeterlilik ile tüm faktörler arasındaki ilişkinin pozitif yönde ve anlamlı olduğu belirlenmiştir. t değeri 1,96'nın üzerinde ise $(p=0,05), 2,56$ 'nin üzerinde ise $(p=0,01)$ düzeyinde anlamlıdır (Schumacker ve Lomax, 2010). Modelde tüm faktörlere ait $t$ değerlerinin ve modelde yer alan faktörlerin t değerlerinin anlamlı olması modelin kabul edilebilirliğinin bir koşuludur. İkinci düzey öz-yeterlilik gizil değişkeni tarafindan birinci düzey değişkenlerde açıklanan varyanslara bakıldığında, birinci düzey değişkenlerden en çok raporlaştırma $\left(R^{2}=0,82\right)$ değişkeninde, en az literatür tarama $\left(R^{2}=0,15\right)$ değişkeninde değişkenlik açıklanmıştır. Sonuç olarak, geliştirilen ölçek $5^{\prime}$ li likert tipinde 37 madde ve 6 faktörlü bir yapıda olduğu belirlenmiştir. Ölçeğin birinci faktörü "Raporlaştırma" 7 madde (1, 2, 3, 4, 5, 6, 7), ikinci faktör "Veri Analizi" 6 madde (8, 9, 10, 11, 12, 13), üçüncü faktör "Literatür Tarama" 7 madde $(14,15,16,17,18,19,20)$, dördüncü faktör "Yöntem" 6 madde (21, 22, 23,24, 25, 26), beşinci faktör "Hipotez(ler)i Belirleme" 5 madde (27, 28, 29, 30, 31) ve son olarak "Problemi Tanımlama" 6 madde $(32,33,34,35,36,37)$ 'den oluşmaktadır. Ölçeğin geneline ait cronbach alpha güvenirlik katsayısı 0,95 olarak hesaplanmışken faktörlerin güvenirlik katsayısı ise sırası ile 0,$92 ; 0,81 ; 0,89 ; 0.89 ; 0,88$ ve 0,86 olarak hesaplanmıştır.

Ölçeğin puanlandırma işleminde herbir düzeye düşen aralığın eşit aralıklı olabilmesi için (n-1)/n formülü uygulanmış ve her düzeye düşen puan 0,80 olarak hesaplanmıştı. Böylece; 1,00-1,80 "Hiç Katılmıyorum",1,81-2,60 "Katılmıyorum", 2,61-3,40 "Kararsızım", 3,41-4,20 "Katlıyorum" ve 4,21-5,00 "Kesinlikle Katllıyorum" şeklinde karşılığı olan değerler belirlenmiştir. Ölçekten alınabilecek en düşük puan 37 iken en yüksek puan ise 185'tir. Ölçeğin faktörlerindeki puan yükseldikçe öğretmenlerin ilgili boyut(lar)a ilişkin özyeterlilik algıları da artmaktadır. Ölçekten alınan toplam puanlar madde sayısına bölünerek, öğretmenlerin elde ettikleri ortalama puanlarına göre, öğretmenlerin bilimsel araşttrmaya yönelik öz yeterlilik algıları konusunda bir yargıya varılabileceği gibi faktörlerde yeralan maddelerde toplanarak ilgili faktördeki madde sayısına bölünerek o faktör hakkında öğretmenlerin öz yeterlilik algıları hakkında fikir sahibi olunabilir.

\section{Kaynakça}

Akçöltekin, A. (2016). Investigation of the effects of trainings on the development of high school teachers' attitudes about scientific researches and project competitions. Educational Sciences: Theory \& Practice, 16, 1349-1380.

Askar, P., \& Umay, A. (2001). Perceived computer self-efficacy of the students in the elementary mathematics teaching programme. Hacettepe University Journal of Education Faculty, 21, 1-8.

Avery, L. M., \& Meyer, D. Z. (2001). Teaching science as science is practiced: Opportunities and limits for enhancing preservice elementary teachers' self-efficacy for science and science teaching. School Science and Matematics, 112 (7), 395-409.

Bieschke, K. J., Bishop, R. M., \& Garcia, V. L. (1993). A factor analysis of the research Self-Efficacy Scale, Paper presented at the Annual Meeting of the American Psychological Association, Toronto, Canada, August 20-24.

Balcı, A. (2009). Sosyal Bilimlerde Araştırma: Yöntem, Teknik ve Illkeler (4.Baskı). Ankara: Pegema Yayıncılık.

Bandura, A. (1995). Self-efficacy in changing societies. New York: Cambridge University Press.

Betoret, F. D. (2009). Self-efficacy, school resources, job stressors and burnout among spanish primary and secondary school teachers: A structural equation approach. Educational Psychology, 23, 45-68.

Brown, T. A. (2006). Confirmatory factor analysis for applied research. NY: Guilford Publications.

Büyüköztürk, Ş. (2002). Faktör analizi: Temel kavramlar ve ölçek geliştirmede kullanımı. Kuram ve Uygulamada Eğitim Yönetimi, 32, 470483.

Büyüköztürk, Ş. (2007). Sosyal bilimler için veri analizi el kitabı (12. baskı). Ankara: Pegem A Yayınları.

Chan, D. W. (2008). General, collective, and domain-specific teacher self-efficacy among chinese prospective and in-service teachers in Hong Kong. Teaching and Teacher Education, 24, 1057- 1069.

Creswell, J.W. (2008). Educational research: Planning, conducting, and evaluating quantitative and qualitative research (3rd edition). New Jersey: Pearson International Education.

Cronbach L. J. (1990). Essentials of psychological testing (5th ed.). New York: Harper Collins Publishers.

Çiltaş, A., Güler, G., \& Sözbilir, M. (2012). Türkiye'de matematik eğitimi araştırmaları: İçerik analizi çalışması. Kuram ve Uygulamada Eğitim Bilimleri, 12(1), 515-580.

Çoban, T. A., \& Sanalan, V. A. (2002). Fen bilgisi öğretimi dersinde özgün deney tasarım sürecinin öğretmen adayının öz yeterlilik algısına etkisi. Erzincan Eğitim Fakültesi Dergisi, 4(2), 1-10.

Demirel, Ö. (2003). Eğitim sözlügü. Ankara: Pegem Yayıncılık. 
Ekiz, D. (2009), Bilimsel Araştırma Yöntemleri (2.Baskı). Ankara: Anı Yayıncılık.

Erkuş, A. (2014). Psikolojide ölçme ve ölçek geliştirme-I temel kavramlar ve işlemler (2. baskı). Ankara: Pegem Akademi.

Fraenkel, J. R., \& Wallen, N. E. (2000). How to design and evaluate research in education. New York: McGraw-Hill.

Fraenkel, J. R., \& Wallen, N. E. (2009). How to design and evaluate research in education (7. Edition). New York: McGraw-Hill.

Godson, I. (1994). Studying teacher's life and work. Teaching and Teachers Education, 10(1), 29-37.

Golightly, T. R. (2007). Defining the components of academic self-efficacy in Navajo American Indian high school students. A PhD dissertation submitted to the faculty of Brigham Young University.

Gorsuch, R. L. (1983). Factor Analysis. Hillsdale: Lawrence Erlbaum Associates.

Gök, B., Kabasakal, K. A., \& Çetin, S. (2015). Araştırmanın yöntem bölümüne ilişkin öz yeterlik ölçeği geliştirilmesi. Illköğretim Online, 14(2), 438-448

Guskey, T.R., \& Passaro, P. (1994). Teacher efficacy: A study of construct dimensions. American Educational Research Journal, 31 (3), $627-643$. Henson, R. K. (2001). The effects of participation in teacher research on teacher efficacy. Teaching and Teacher Education, 17(7), 819-836.

Hooper, D., Coughlan, J., \& Mullen, M. (2008). Structural equation modeling: Guidelines for determining model fit. The Electronic Journal of Business Research Methods, 6 (1), 53-60.

House, J. D. (2004). Cognitive-motivational characteristics and science achievement of adolescent students: Results from the TIMSS 1995 and timss 1999 assesments. International Journal of Instructional Media, 31 (4).

İlhan, A, Çelik, H. C., \& Aslan, A. (2016). Evaluating the attitudes of university students about scientific research. Inönü University Journal of the Faculty of Education, 17(2), 141-156.

İpek, C., Tekbıyık, A., \& Ursavaş, Ö. F. (2010). Lisansüstü öğrencilerinin araştırma öz-yeterlik inançları ve bilgisayar tutumları. Gaziantep Üniversitesi Sosyal Bilimler Dergisi, 9(1), 127-145.

Jaipal-Jamani, K., \& Angeli, C. (2017). Effect of robotics on elementary preservice teachers' self-efficacy, science learning, and computational thinking. Journal of Science Education and Technology, (26) 2, 175-192.

Jöreskog, K. G., \& Sörbom, D. (1993). LISREL 8: Structural equation modeling with the simplis command language. Lincolnwood: Scientific Software International, Inc.

Karasar, N. (2000). Bilimsel Araştırma Yöntemi. Ankara: Nobel Yayın Dağıtım

Karasar, N. (2013). Bilimsel araştırma yöntemleri. Ankara: Nobel Yayın Dağıtım.

Kart, A., \& Gelbal, S. (2014). Öğretmen adaylarının bilimsel araştırma öz yeterlik algılarının ikili karşılaştırmalı yargılar yöntemiyle belirlenmesi. Eğitimde ve Psikolojide Ölçme ve Değerlendirme Dergisi, 5(1), 12-23.

Kelloway, E. K. (1998). Using lisrel for structural equation modeling. Thousand Oaks, CA: Sage.

Khan, A., Fleva, E. \& Qazi, T. (2015). The role of self-esteem and general selfefficacy in teachers' efficacy in primary schools. Psychology, 6 (1), 117-125.

Kline, P. (1994). An easy guide to factor analysis. London: Routledge.

Kline, R. B. (1998). Principles and Practice of Structural Equation Modeling, New York: Guilford Press.

Kline, R. B. (2005). Principles and practice of structural equation modelling. New York: Guilford Publications, Inc.

Korkmaz, Ö., Şahin, A., \& Yeşil, R. (2011). Bilimsel araştırmaya yönelik tutum ölçeği geçerlilik ve güvenirlik çalışması. Ilköğretim Online, 10 (3), 962-973.

Kurbanoğlu, S. S. (2004). Öz-yeterlik inancı ve bilgi profesyonelleri için önemi. Bilgi Dünyası, 5(2), 137-152

Küçükyılmaz, E. A., \& Duban, N. (2006). Sınıf öğretmeni adaylarının fen öğretimi öz yeterlik inançlarının artırılabilmesi için alınacak önlemlere ilişkin görüşleri. Yüzüncü Yıl Üniversitesi Eğitim Fakültesi Dergisi, 3(2), 1-23.

Lane, A. M., Hall, R., \& Lane, J. (2004). Self-efficacy and statistics performance among Sport Studies students. Teaching in Higher Education, 9(4), 435-448.

Ihan, A.; Celik, H. C., \& Aslan, A. (2016). Evaluating the attitudes of university students about scientific research. Inonu University Journal of the Faculty of Education, 17(2), 141-156.

MEB. (2008). Öğretmen yeterlikleri: öğretmenlik mesleği genel ve özel alan yeterlikleri. Öğretmen Yetiştirme ve Eğitimi Genel Müdürlüğü. Ankara: Milli Eğitim Müdürlüğü Devlet Kitapları Müdürlüğü.

Menon, D., \& Sadler, T.D. (2017). Sources of science teaching self-efficacy for preservice elementary teachers in science content courses. International Journal of Science and Mathematics Education, (4), 1-21,

Peers, I. (1996). Statistical analysis for education and psychology researchers: Tools for researchers in education and psychology. London: Falmer Press.

Punch, K. F. (2005). Introduction to social research-quantitative \& qualitative approaches. London: Sage

Saracaloğlu, A. S. (2008). Lisansüstü öğrencilerin akademik güdülenme düzeyleri, araştırma kaygıları ve tutumları ile araştırma yeterlikleri arasındaki ilişki. Yüzüncü Yıl Üniversitesi Eğitim Fakültesi Dergisi, 4(2), 179-208.

Schumacker, R. E., \& Lomax, R. G. (1996). A beginner's guide to structural equation modeling. New Jersey: Lawrence Erlbaum Associates, Inc.

Schumacker, R. E., \& Lomax, R. G. (2010). A beginner's guide to structural equation modeling. New York, NY: Taylor \& Francis Group.

|Kastamonu Eğitim Dergisi, 27(6), 2019| 
Schunk, D. H. (2011). Learning theories: An educational perspective. Pearson Education, Inc.

Schunk, D. H., \& Pajares, F. (2002). The development of academic self-efficacy; chapter in Development of Achievement Motivation, Wigfield, A., and Eccles, J. (Ed.) San Diego: Academic Press.

Senemoglu, N. (2007). Gelişim ögrenme ve ögretim. Ankara: Gönül Yayincilik.

Skaalvik, E. M., \& Skaalvik, S. (2010). Teacher self-efficacy and teacher burnout: A study of relations. Teaching and Teacher Education, 26 (4), 1059-1069.

Sümer, N. (2000). Yapısal Eşitlik Modelleri. Türk Psikoloji Yayınları, 3(6), 49-74.

Şimşek, Ö. F. (2007). Yapısal eşitlik modellemesine giriş: Temel ilkeler ve LISREL uygulamaları. Ankara: Ekinoks Yayınevi.

Taşdemir, M., \& Taşdemir, A. (2011). Öğretmen adaylarının bilimsel araştırmaları inceleme yeterlilikleri. Selçuk Üniversitesi Sosyal Bilimler Enstitüsü Dergisi, 26, 344-353.

Thompson, B. (2004). Exploratory and confirmatory factor analysis: Understanding concepts and applications. Washington: American Psychological Association.

Tuncer, M., \& Özeren, E. (2012). The development of a self-efficacy scale for scientific research and an evaluation of prospective teachers' views about that scale. Social and Behavioral Sciences, 51, 553-561.

Tuncer, M., \& Yılmaz, Ö. (2017). Üst biliş düşünme becerileri ve bilimsel araştırma öz yeterliği arasındaki ilişkinin regresyon analizi ve yapısal eşitlik modeli ile incelenmesi. Journal of Human Sciences, 14(2), 1273-1283.

Woolfolk- Hoy, A., \& Burke-Spero, R. (2005). Changes in teacher efficacy during the early years of teaching: A comparison of four measures. Teaching and Teacher Education, 21, 343-356.

Yaşar, M. (2014). Bilimsel araştırma yöntemleri dersine yönelik tutum ölçeği geliştirme çalışması: Geçerlik ve güvenirlik. Eğitim Bilimleri Araştırmaları Dergisi, 4(2), 109-129.

Yıldııım, A. ve Şimşek, H. (2008). Sosyal bilimlerde nitel araştırma yöntemleri (6.basım), Ankara: Seçkin Yayıncılık.

Yukselturk, E., \& Altiok, S. (2017). An investigation of the effects of programming with Scratch on the preservice IT teachers' self-efficacy perceptions and attitudes towards computer programming. British Journal of Educational Technology, 48(3), $789-801$.

Yurdagül, H. (2005). Ölçek geliştirme çalışmalarında kapsam geçerlik indeksinin kullanımı. 14. Eğitim Bilimleri Kongresi, Pamukkale Üniversitesi, Denizli.

Yücel Toy, B., \& Güneri Tosunoğlu, N. (2007). Sosyal bilimler alanındaki araştırmalarda bilimsel araştrrma süreci, istatistiksel teknikler ve yapılan hatalar. Gazi Üniversitesi Ticaret ve Turizm Eğitim Fakültesi Dergisi, 1, 1-22.

Zimmerman, B. J. (1995). Self-efficacy and educational development, In A. Bandura (Ed.). Self-efficacy in changing societies, 46-68 New York: Cambridge University Press. 